\title{
Pengembangan LKPD Berbasis Materi Prasyarat Terstruktur pada Materi Persamaan Garis Lurus untuk Kelas VIII SMP/MTs
}

\section{Development of LKPD Based on Structured Prerequisite Material on Straight Line Equation Material for VIII SMP/MTs Class}

\author{
Sariyani SN*, Jefri Marzal, Syaiful \\ Program Studi Magister Pendidikan IPA Universitas Jambi \\ *coresponding author: sariyani_sn@yahoo.com
}

\begin{abstract}
Mastery of the prerequisite material is essential to help students overcome mathematics learning difficulties; however, the prerequisite material needs to be managed effectively to achieve learning objectives. Student Worksheet (LKPD) is a learning tool that can be used to achieve learning objectives. This research is development research to produce a student worksheet that is valid, practical, and effective. LKPD development is carried out using the ADDIE model. The valid value is obtained from the results of content validation by the validator. The practical value is obtained from the test subject's response, and the effectiveness value is obtained based on the assessment of students during the actual trial. The development results show that the average percentage score of the validation results of material experts and media experts reaches $72 \%$, which indicates that LKPD is valid. The practicality assessment was obtained from the percentage of student and teacher responses to the questionnaire given; the average is $99 \%$. The trial results show that the students' responses are very valid. Student learning outcomes showed that $76 \%$ of students were able to reach the minimum requirement achievement, meaning that the LKPD effectively improved student learning outcomes. Mathematical LKPD based on structured prerequisite material fulfills the valid, practical, and effective criteria for learning straight line equation material.
\end{abstract}

Keywords: Learning difficulties, mathematics learning, teaching materials

\begin{abstract}
Abstrak
Penguasaan materi prasyarat penting untuk membantu peserta didik mengatasi kesulitan belajar matematika, namun materi prasyarat perlu dikelola secara efektif agar tercapai tujuan pembelajaran. LKPD (Lembar Kerja Peserta Didik) merupakan perangkat pembelajaran yang dapat digunakan untuk mencapai tujuan pembelajaran. Penelitian ini merupakan penelitian pengembangan untuk menghasilkan LKPD yang valid, praktis, dan efektif. Pengembangan LKPD dilakukan menggunakan model ADDIE. Nilai valid diperoleh dari hasil validasi isi oleh validator, nilai praktis diperoleh dari respon subjek uji coba, serta nilai keefektifan diperoleh berdasarkan penilaian peserta didik saat uji coba sebenarnya. Hasil pengembangan memperlihatkan rata-rata persentase skor hasil validasi ahli materi dan ahli media mencapai $72 \%$ yang menunjukkan LKPD valid. Penilaian kepraktisan diperoleh dari persentase jawaban respon peserta didik dan guru pada angket yang diberikan pada tiga tahap uji coba dengan rata-rata mencapai 99\%. Hasil ujicoba menunjukkan bahwa respon peserta didik sangat valid. Hasil belajar peserta didik menunjukkan $76 \%$ peserta didik mencapai ketuntasan, berarti LKPD efektif dalam meningkatkan hasil belajar peserta didik. LKPD matematika berbasis materi prasyarat terstruktur memenuhi kriteria valid, praktis, dan efektif digunakan dalam pembelajaran materi persamaan garis lurus.
\end{abstract}

Kata Kunci: Bahan ajar, kesulitan belajar, pembelajaran matematika 


\section{PENDAHULUAN}

Ruang lingkup mata pelajaran matematika SMP/MTs ditinjau dari aspek materi pelajaran meliputi bilangan, aljabar, geometri dan pengukuran, serta statistika dan peluang. Materi persamaan garis lurus merupakan salah satu materi aljabar di kelas VIII semester ganjil pada kurikulum 2013. Relevansi materi persamaan garis lurus dengan mata pelajaran lain, diantaranya diterapkan dalam materi perhitungan kecepatan, percepatan, gaya, keuntungan mekanis bidang miring, dan suhu dalam fisika serta perhitungan harga barang dan titik impas dalam mata pelajaran ekonomi. Persamaan garis lurus juga dapat diaplikasikan diberbagai bidang kehidupan, misalnya penelitian, teknik bangunan, transportasi, dan kesehatan.

Penguasaan materi garis lurus berdampak positif terhadap tujuan pembelajaran matematika. Materi tersebut membantu meningkatkan kemampuan peserta didik dalam memecahkan masalah yang meliputi kemampuan memahami masalah, merancang model, menyelesaikan model dan menafsirkan solusi yang diperoleh, serta kemampuan mengomunikasikan gagasan dalam bentuk simbol, tabel, atau diagram untuk memperjelas suatu keadaan atau masalah.

Penguasaan terhadap materi garis lurus dapat dilihat dari hasil penilaian harian. Untuk materi persamaan garis lurus secara klasikal belum mencapai keberhasilan kelas. Dalam teori tuntas, keberhasilan kelas dapat dilihat jika minimal $75 \%$ dari jumlah peserta didik mampu mencapai KKM (Djamarah \& Zain, 2010). Hasil belajar yang belum mencapai ketuntasan materi garis lurus merupakan indikasi adanya kesulitan belajar peserta didik pada materi tersebut. Sebagaimana dinyatakan Suningsih dkk., (2014) bahwa rendahnya penguasaan materi persamaan garis lurus disebabkan oleh kesulitan peserta didik dalam mempelajari materi persamaan garis lurus.

Hasil survei P4TK pada monitoring dan evaluasi program BERMUTU tahun 2010 menunjukkan bahwa materi persamaan garis lurus sulit dipahami peserta didik dan menjadi permasalahan pembelajaran bagi guru. Dipertegas dalam penelitian diagnosis kesulitan belajar matematika SMP pada materi persamaan garis lurus oleh Tanjungsari \& Soedjoko (2012) bahwa kesulitan peserta didik mempelajari persamaan garis lurus disebabkan kurangnya penguasaan dasar-dasar aljabar, kesalahan dalam komputasi aljabar, serta kesalahan dalam operasi bilangan. Hal senada pun dikemukakan oleh Maisura (2014) bahwa masih banyak peserta didik yang mengalami kesalahan operasi, prinsip, dan kealpaan dalam menyelesaikan soal persamaan garis lurus.

Materi prasyarat merupakan materi yang pernah dipelajari dan masih berkaitan dengan materi yang akan dipelajari. Tes kemampuan prasyarat dilakukan untuk mengetahui kemampuan prasyarat peserta didik kelas VIII meliputi soal-soal operasi bilangan bulat, aljabar, dan sistem koordinat. Hasil tes menunjukkan bahwa $35,48 \%$ peserta didik kurang mampu dan $64,52 \%$ tidak mampu dalam menguasai materi prasyarat.

Penguasaan materi prasyarat penting untuk peserta didik dalam mengatasi kesulitan belajar pada materi persamaan garis lurus, namun masalahnya adalah bagaimana mengelola materi prasyarat dalam pembelajaran secara efektif untuk mencapai tujuan pembelajaran. Menurut Hidayanto (2013) bahwa pembelajaran dapat dipandang dari dua dimensi, yaitu sebagai proses penyampaian materi dan pengaturan lingkungan peserta didik agar dapat belajar. Jika pembelajaran merupakan proses penyampaian materi, 
maka pembelajaran membutuhkan bahan ajar yang dapat menyalurkan pesan secara efektif dan efisien.

Salah satu bahan ajar dalam proses pembelajaran yang dapat menyampaikan pesan kepada peserta didik adalah LKPD. Berdasarkan hasil penelitian Wulandari \& Sunardi (2014) LKPD dinilai efektif dalam memperbaiki aktifitas dan hasil belajar peserta didik. Khusus untuk materi pembelajaran persamaan garis lurus, Dwi dkk., (2012) menyatakan bahwa pembelajaran menggunakan LKPD mampu meningkatkan aktivitas peserta didik, meningkatkan ketuntasan belajar, serta meningkatkan respon positif peserta didik.

Berdasarkan pengamatan penggunaan LKPD konvensional oleh guru dalam pembelajaran matematika, selain telah tersajinya ringkasan materi, soal-soal latihan, dan uji kompetensi, LKPD juga telah memuat pendahuluan yang meliputi penyajian $\mathrm{KD}$, tujuan pembelajaran, sejarah penemuan konsep, dan aplikasi materi dalam kehidupan sehari-hari. Kekurangannya LKPD masih belum menyajikan materi prasyarat yang harus dikuasai peserta didik sebelum mempelajari materi pokok. Menurut Ausubel dalam teori kebermaknaan, pengulangan materi sangat penting sebelum belajar dimulai. Artikel ini menjelaskan bagaimana pengembangan LKPD berbasis materi prasyarat terstruktur yang valid, praktis, dan efektif pada materi persamaan garis lurus.

\section{METODE PENELITIAN}

Penelitian dilakukan pada peserta didik kelas VIII (delapan) MTs Negeri 6 Batanghari Propinsi Jambi. Penelitian dilaksanakan pada semester ganjil tahun pelajaran 2017/2018. Subjek penelitian terdiri dari kelas uji coba berjumlah 34 peserta didik dan kelas kontrol berjumlah 31 peserta didik.
Pengembangan LKPD Matematika menggunakan lima tahap ADDIE yaitu Analysis, Design, Development, Implementation dan Evaluation. Model pengembangan produk menggunakan model ADDIE (Gambar 1):

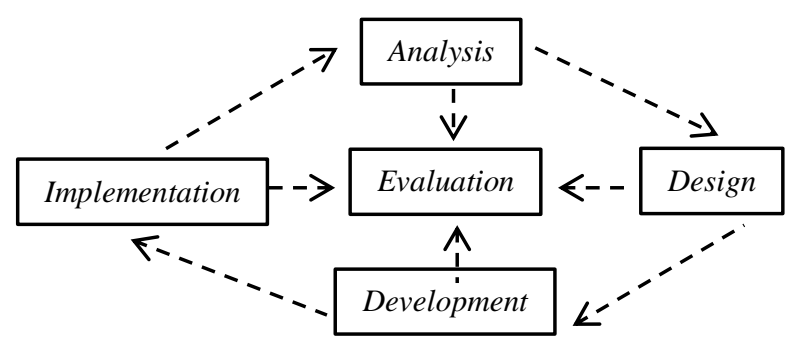

Gambar 1. Diagram Model ADDIE

Analisis terdiri dari dua tahap yaitu analisis kinerja (performance analysis) dan analisis kebutuhan (need analysis). Analisis kinerja meliputi analisis kurikulum yang menjadi dasar dalam menganalisis pengetahuan, sikap, dan keterampilan peserta didik pada proses pembelajaran. Analisis kurikulum 2013 dilakukan untuk menetapkan dan mendefinisikan kebutuhan-pembelajaran. Analisis kurikulum berhubungan dengan aspek teori yang tercantum dalam dokumen Standar Isi (SI) yang mencakup lingkup materi dan tingkat kompetensi untuk mencapai kompetensi lulusan pada jenjang sekolah menengah. Selanjutnya analisis karakteristik peserta didik juga diperlukan untuk mengetahui kemampuan akademik individu, kemampuan prasyarat, dan minat peserta didik terhadap mata pelajaran matematika. Hasil analisis dijadikan gambaran untuk mengembangkan LKPD yang sesuai dengan karakteristik peserta didik.

Analisis kebutuhan dilakukan untuk menganalisis permasalahan belajar dan kebutuhan peserta didik pada mata pelajaran matematika. Berdasarkan analisis tersebut diperoleh masalah-masalah yang melatarbelakangi suatu solusi atau pengembangan bahan ajar/media. Data dikumpulkan dari studi lapangan dan didukung oleh studi literatur. Studi literatur dilakukan dengan 
cara mengkaji teori melalui buku-buku dan sumber informasi lainnya yang relevan.

Tahap perancangan bertujuan untuk merancang LKPD terkait materi persamaan garis lurus. Kegiatan-kegiatan pada tahap ini adalah menyusun peta kebutuhan LKPD, menentukan judul LKPD, dan penulisan LKPD. Langkahlangkah yang dilakukan meliputi merumuskan kompetensi dasar, menentukan alat penilaian, dan menyusun materi.

Tahap pengembangan bertujuan untuk menghasilkan LKPD yang telah direvisi berdasarkan masukan dari para ahli. Validasi dilakukan oleh tim ahli yang terdiri dari ahli materi dan ahli media. Setelah produk divalidasi oleh tim ahli, selanjutnya peneliti melakukan revisi produk berdasarkan masukan dari para ahli tersebut.

Pada tahap implementasi, produk yang telah direvisi, diuji-cobakan pada kelompok kecil, kelompok besar, dan pada kondisi kelas sebenarnya. Hasil dari tiap tahap uji coba menjadi masukan dalam merevisi LKPD. Melalui tahap uji coba, diperoleh data respon peserta didik dan guru terhadap produk LKPD serta hasil belajar peserta didik. Hasil uji coba berupa respon peserta didik dan penilaian hasil belajar, selanjutnya dianalisis pada tahap evaluasi untuk mengetahui tingkat kepraktisan dan keefektifan LKPD. Perangkat pembelajaran dikatakan praktis jika perangkat tersebut mudah digunakan dan dikatakan efektif jika pemanfaatannya memberikan dampak positif terhadap hasil belajar peserta didik yang ditunjukkan dengan tercapainya ketuntasan belajar secara klasikal.

Data yang dihasilkan dari pengembangan adalah data kualitatif dan kuantitatif. Data kualitatif diperoleh dari hasil analisis kebutuhan, saran dan komentar oleh validator, serta respon peserta didik dan guru pada tahap uji coba. Data kuantitatif diperoleh dari tes prasyarat dan penilaian hasil belajar.

Instrumen yang digunakan dalam pengembangan LKPD ini adalah angket analisis kebutuhan serta angket validasi LKPD. Angket validasi diberikan kepada tim ahli (ahli materi dan media) untuk menilai kevalidan LKPD berdasarkan pada landasan teori dan kajian pustaka. Pengukuran dilakukan menggunakan skala Likert, dengan skala 4 (Sangat Se-suai), 3 (Sesuai), 2 (Kurang Sesuai), dan 1 (Tidak Sesuai). Angket respon pengguna LKPD diberikan kepada pengguna untuk memperoleh data respon peserta didik dan guru terhadap penggunaan LKPD dalam pembelajaran. Pengukuran dilakukan menggunakan skala Guttman: skala 1 (Ya) dan 0 (Tidak). Angket digunakan untuk mengetahui kepraktisan penggunaan LKPD. Pengukuran lainnya dilakukan dalam bentuk tes prasyarat. Pada penelitian pendahuluan, tes digunakan untuk mengetahui kemampuan prasyarat yang meliputi kemampuan menyelesaikan operasi bilangan bulat dan aljabar, menggunakan koordinat kartesius untuk menentukan posisi suatu titik, serta memahami posisi dua garis yang sejajar dan tegak lurus dalam bidang Kartesius. Tes hasil belajar dilaksanakan setelah LKPD selesai digunakan yang bertujuan untuk mendapatkan data hasil belajar peserta didik. Teknik tes berupa essay yang disusun berdasarkan indikator pembelajaran pada materi persamaan garis lurus yang dituangkan dalam kisi-kisi tes. Pemberian tes digunakan untuk mengetahui keefektifan penggunaan LKPD.

Analisis data yang digunakan adalah analisis deskriptif kualitatif dalam bentuk persentase yang dihitung mengikuti rumus Ali (Rohmad dkk., 2012)

$\mathrm{P}=\frac{\mathrm{n}}{\mathrm{N}} \times 100 \%$

Keterangan:

$\mathrm{P}=$ persentase skor $(\%)$ 
$\mathrm{n}=$ jumlah skor yang diperoleh

$\mathrm{N}=$ jumlah skor maksimum

Kriteria yang digunakan untuk menginterpretasi hasil analisis adalah sebagai berikut.

Tabel 1. Kriteria Persentase Valid/Praktis

\begin{tabular}{cl}
\hline Interval Skor & \multicolumn{1}{c}{ Kriteria } \\
\hline $75 \% \leq \mathrm{P} \leq 100 \%$ & Sangat Valid/Praktis \\
$50 \% \leq \mathrm{P}<75 \%$ & Valid/Praktis \\
$25 \% \leq \mathrm{P}<50 \%$ & Kurang Valid/Praktis \\
$0 \% \leq \mathrm{P}<25 \%$ & Tidak Valid/Praktis \\
\hline
\end{tabular}

Kriteria ketuntasan peserta didik berdasarkan KKM matematika kelas VIII MTsN Muara Tembesi Tahun Pelajaran 2017/2018, digunakan untuk menentukan kriteria efektif dengan cara:

a. tabulasi data tes hasil belajar

b. menghitung persentase jumlah peserta didik yang tuntas, dengan rumus:

$$
\frac{\text { Banyak peserta didik yang tuntas }}{\text { Jumlah peserta didik }} \times 100 \%
$$

c. kriteria yang digunakan untuk menginterpretasikan hasil analisis sebagai berikut.

Tabel 2. Kriteria Persentase Efektif

\begin{tabular}{cl}
\hline Interval Persentase & \multicolumn{1}{c}{ Kriteria } \\
\hline $\mathrm{T}>99 \%$ & Sangat Efektif \\
$75 \% \leq \mathrm{P} \leq 99 \%$ & Efektif \\
$60 \% \leq \mathrm{P}<75 \%$ & Kurang Efektif \\
$\mathrm{T}<60 \%$ & Tidak Efektif \\
\hline
\end{tabular}

(Djamarah \& Zain, 2010)

\section{HASIL DAN PEMBAHASAN}

Analisis peserta didik dilakukan untuk mengetahui tingkat kemampuan rata-rata, kemampuan prasyarat, dan minat peserta didik terhadap mata pelajaran matematika. Berdasarkan data yang dikumpulkan diperoleh tingkat kemampuan rata-rata peserta didik kelas VIII pada tingkat pencapaian KKM pada kelas sebelumnya yakni 65 (masuk dalam interval 65 - 80) yang termasuk dalam kriteria sedang. Kemampuan prasyarat materi persamaan garis lurus sebanyak $35,48 \%$ siswa termasuk dalam kategori kurang mampu dan $64,52 \%$ siswa termasuk dalam kategori tidak mampu dalam menguasai materi prasyarat. Dari data tersebut terlihat bahwa peserta didik kelas VIII masih bermasalah dalam penguasaan materi prasyarat yang meliputi operasi bilangan bulat, aljabar, dan sistem koordinat. Menurut Hidayat (2013) peserta didik yang belum menguasai materi prasyarat akan mengalami kesulitan dalam mempelajari materi baru. Mengingat pentingnya menguasai materi prasyarat untuk mempelajari persamaan garis lurus, oleh karena itu peserta didik harus diingatkan kembali tentang materi prasyarat, baik dalam kegiatan apersepsi maupun kegiatan lain yang membutuhkan materi prasyarat.

Minat peserta didik terhadap mata pelajaran matematika menunjukkan bahwa sebanyak $35,48 \%$ siswa termasuk dalam kategori berminat dan $61,29 \%$ siswa termasuk dalam kategori sangat berminat. Hasil analisis minat menunjukkan bahwa peserta didik memiliki minat positif terhadap mata pelajaran matematika. Menurut Susanto (2013) minat memberikan pengaruh yang signifikan terhadap keberhasilan belajar. Fakta di lapangan menunjukkan hasil yang berbeda. Meskipun peserta didik memiliki minat yang baik terhadap mata pelajaran matematika namun secara klasikal belum mampu mencapai keberhasilan belajar. Belum tercapainya tujuan pembelajaran menunjukkan bahwa guru belum berhasil dalam mengajar. Guru perlu melakukan analisis terhadap kegiatan pembelajaran yang telah dilakukan.

Bahan pelajaran adalah substansi yang akan disampaikan dalam proses pembelajaran. Bahan pembelajaran yang digunakan guru dan peserta didik di kelas hanya terbatas pada buku teks yang tersedia di perpustakaan sekolah. Keterbatasan bahan pustaka 
dimungkinkan menjadi penyebab belum tercapainya tujuan pembelajaran, karena pembelajaran di kelas belum memadai tanpa didukung oleh banyak membaca buku atau studi pustaka. Menurut Sumiati \& Asra (2009) buku dan perpustakaan mempunyai nilai yang sangat tinggi dalam menunjang keberhasilan belajar. Dampak dari terbatasnya bahan pembelajaran adalah pembelajaran di kelas menjadi cenderung lebih berpusat pada guru, peserta didik hanya menerima apa yang disampaikan oleh guru. Seharusnya peserta didik lebih aktif daripada guru dalam interaksi tersebut.

Interaksi dikatakan maksimal bila terjadi interaksi baik antara peserta didik dengan guru, peserta didik dengan peserta didik, maupun antara peserta didik dengan lingkungan belajar untuk mencapai tujuan belajar (Djamarah \& Zain, 2010). Kecenderungan guru untuk menggunakan metode pembelajaran yang sama untuk semua materi dapat menjadi penyebab kegagalan dalam pencapaian tujuan pembelajaran. Peserta didik menjadi bosan dan tidak tertarik dengan pembelajaran yang sedang berlangsung, sehingga pembelajaran tidak berjalan dengan efektif, sehingga akhirnya berdampak negatif terhadap penguasaan tujuan pembelajaran. Sebagaimana disampaikan (Djamarah \& Zain, 2010) bahwa metode pembelajaran merupakan salah satu komponen pembelajaran yang menentukan keberhasilan pembelajaran. Penjelasan tersebut didukung oleh Susanto (2013) yang menyatakan bahwa minat memberikan sumbangan besar terhadap keberhasilan belajar peserta didik, namun bahan pelajaran, pendekatan, ataupun metode yang tidak sesuai dengan minat peserta didik menyebabkan hasil belajar tidak optimal.

Hasil studi lapangan berdasarkan pengalaman guru matematika di MTsN 6 Batanghari, bahwa materi persamaan garis lurus masih sulit dipahami peserta didik dan menjadi permasalahan pembelajaran bagi guru. Hasil analisis penilaian harian untuk materi persamaan garis lurus pada tiga tahun terakhir (Tahun Pelajaran 2014 /2015 s.d 2016/2017) secara klasikal peserta didik belum mencapai ketuntasan belajar. Hal ini juga dipengaruhi oleh terbatasnya sumber-sumber belajar yang terdapat di MTsN 6 Batanghari. Pemanfaatan media cetak hanya berupa buku teks yang tersedia di perpustakaan sekolah, yang tidak memenuhi kebutuhan buku teks pelajaran untuk semua peserta didik.

Berdasarkan analisis kebutuhan, ditemukan permasalahan belajar yaitu tidak tercapainya tujuan pembelajaran. Hal ini terlihat dari hasil belajar Sebagian besar peserta didik yang tidak mencapai KKM $(\geq 68)$, dan secara klasikal belum mencapai ketuntasan kelas. Menurut Hidayanto (2013) tercapainya tujuan pembelajaran tidak terlepas dari kegiatan pembelajaran yang dilakukan. Pembelajaran dapat dipandang dari dua dimensi, yaitu sebagai proses penyampaian materi dan proses pengaturan lingkungan peserta didik agar dapat belajar. Dalam aspek proses penyampaian materi, pembelajaran membutuhkan bahan ajar yang dapat menyalurkan pesan secara efektif dan efisien.

Keterbatasan buku sebagai sumber belajar peserta didik di MTsN 6 Batanghari menyebabkan guru cenderung untuk menerapkan pembelajaran langsung. Dalyono (Hidayati, 2010) menyampaikan bahwa terbatasnya sarana belajar akan menghambat kemajuan peserta didik dalam belajar. Sarana belajar bisa berupa literatur, alat/media belajar, dan ruang tempat belajar. Literatur merupakan sumber belajar yang dapat dipergunakan oleh peserta didik untuk memperluas pengetahuan dan pemahaman terhadap suatu materi. Adanya kesempatan belajar yang lebih luas dalam menggunakan literatur akan membantu peserta didik 
dalam mengatasi kesulitan belajar. Gambaran kebutuhan peserta didik akan media cetak pembelajaran tersaji pada Tabel 3

Tabel 3. Hasil Analisis Kebutuhan Peserta Didik akan Pemanfaatan Media Cetak Pembelajaran

\begin{tabular}{clcc}
\hline No & \multicolumn{1}{c}{ Pernyataan } & $\begin{array}{c}\text { Persentase } \\
\text { Skor }\end{array}$ \\
\hline 1 & $\begin{array}{l}\text { Kemudahan peserta didik } \\
\text { mempelajari } \\
\text { buku teks } \\
\text { Kemudahan peserta didik } \\
\text { mempelajari materi dalam }\end{array}$ & $88 \%$ \\
2 & $\begin{array}{l}\text { LKPD } \\
\text { Perlunya penyajian materi } \\
\text { prasyarat dalam LKPD }\end{array}$ & $91 \%$ \\
4 & $\begin{array}{l}\text { Perlunya pengembangan } \\
\text { LKPD }\end{array}$ & $88 \%$ \\
\hline
\end{tabular}

Tahap design bertujuan merancang LKPD pada materi persamaan garis lurus. Kegiatan yang dilakukan pada design yaitu menyusun peta kebutuhan LKPD. Materi yang disajikan pada LKPD meliputi materi prasyarat (Operasi Bilangan Bulat, Sistem Koordinat, dan PLSV), serta materi persamaan garis lurus yang mencakup tiga sub materi, yaitu materi menggambar grafik garis lurus, menentukan kemiringan garis lurus, dan menentukan persamaan garis lurus. Judul yang digunakan pada produk LKPD ditentukan berdasarkan materi pembelajaran yang terdapat dalam kurikulum 2013, yaitu LKPD Matematika Berbasis Materi Prasyarat Terstruktur pada Materi Persamaan Garis Lurus Kelas VIII SMP/MTs. Langkah selanjutnya adalah penulisan secara sistematis sesuai dengan struktur LKPD yang dilengkapi dengan soal-soal latihan yang bervariasi. Tampilan LKPD didukung dengan gambar-gambar pendukung yang berwarna untuk menarik perhatian peserta didik.

Isi LKPD diawali dengan penyajian singkat materi prasyarat terstruktur disertai contoh langkah-langkah penyelesaian. Penyajian konsep materi prasyarat tidak hanya di awal pembelajaran namun juga diberikan pada langkah-langkah penyelesaian tertentu dimana peserta didik diingatkan untuk bisa menyelesaikan langkah-langkah selanjutnya. Hasil penelitian Mahdi (2012) menunjukkan bahwa pemberian materi prasyarat dilaksanakan tidak hanya diawal pembelajaran, tetapi juga saat pembelajaran inti berlangsung, sehingga pemberian materi prasyarat tidak bisa terlepas dari proses pembelajaran secara keseluruhan. Pembelajaran matematika dengan LKPD berbasis materi prasyarat terstruktur menggunakan langkah-langkah pendekatan saintifik dapat mengkonstruksi pengetahuannya melalui kegiatan mengamati, bertanya, mengumpulkan informasi, menalar, dan mengomunikasikan. Contoh-contoh soal dalam setiap kegiatan selalu disertai langkah-langkah penyelesaian yang terstruktur supaya peserta didik dapat lebih memahami materi dan dapat meningkatkan keterampilannya dalam menyelesaikan soal-soal. Peserta didik pun diberi kesempatan untuk melanjutkan langkahlangkah penyelesaiannya sendiri. Diharapkan pengembangan LKPD ini dapat membantu peserta didik dalam mempelajari matematika.

Produk LKPD yang dihasilkan kemudian validasi untuk memperoleh nilai kevalidan dari LKPD. Hasil validasi oleh ahli materi disajikan pada Tabel 4, sedangkan hasil validasi oleh ahli media disajikan pada Tabel 5. Hasil validasi ahli media dan ahli materi diperoleh rata-rata persentase skor $72 \%$, yang menunjukkan bahwa LKPD berbasis materi prasyarat terstruktur dinyatakan valid. 
Tabel 4.Tabulasi Hasil Validasi Materi terhadap LKPD Pengembangan

\begin{tabular}{|c|c|c|}
\hline No & Pernyataan & Skor \\
\hline 1. & $\begin{array}{l}\text { Bagaimana kesesuaian materi LKPD dengan pencapaian KI dan KD materi persamaan garis } \\
\text { lurus }\end{array}$ & 1 \\
\hline 2. & Bagaimana keluasan lingkup materi LKPD terhadap tujuan pembelajaran yang hendak dicapai? & 2 \\
\hline 3. & Bagaimana kedalaman materi LKPD terhadap kompetensi yang harus dikuasai peserta didik? & 2 \\
\hline 4. & Bagaimana ketepatan urutan materi LKPD? & 3 \\
\hline 5. & Bagaimana dengan kebenaran fakta, konsep, operasi, dan prinsip pada materi LKPD? & 3 \\
\hline 6. & Bagaimana keaktualan materi LKPD terhadap perkembangan zaman? & 1 \\
\hline 7. & $\begin{array}{l}\text { Bagaimana kemungkinan materi untuk dipelajari peserta didik jika dilihat dari tingkat } \\
\text { kesulitan? }\end{array}$ & 2 \\
\hline 8. & Bagaimana kesesuaian materi terhadap tingkat perkembangan kecerdasan peserta didik? & 2 \\
\hline 9. & Bagaimana kesesuaian/ketepatan penyajian ilustrasi materi dalam LKPD? & 2 \\
\hline 10. & Bagaimana format penilaian hasil belajar dalam LKPD? & 2 \\
\hline 11. & Bagaimana kesesuaian tugas mandiri terhadap tujuan pembelajaran? & 3 \\
\hline 12. & Bagaimana kesesuaian tugas kelompok terhadap tujuan pembelajaran? & 2 \\
\hline 13. & Bagaimana dengan variasi soal-soal dalam LKPD? & 1 \\
\hline 14. & Bagaimana kesesuaian bahasa terhadap tingkat perkembangan peserta didik? & 2 \\
\hline 15. & Bagaimana dengan penggunaan bahasa komunikatif dalam LKPD? & 3 \\
\hline 16. & Bagaimana kesesuaian materi prasyarat terhadap materi pembelajaran persamaan garis lurus? & 4 \\
\hline 17. & $\begin{array}{l}\text { Bagaimana kesesuaian lingkup materi prasyarat terhadap tujuan pembelajaran persamaan garis } \\
\text { lurus? }\end{array}$ & 2 \\
\hline 18. & $\begin{array}{l}\text { Bagaimana peran materi prasyarat terstruktur dalam mendukung langkah-langkah penyelesaian } \\
\text { soal dalam LKPD? }\end{array}$ & 1 \\
\hline \multirow[t]{4}{*}{19.} & $\begin{array}{l}\text { Bagaimana ketepatan penempatan materi prasyarat terstruktur dalam LKPD terhadap } \\
\text { kebutuhan pembelajaran? }\end{array}$ & 2 \\
\hline & Total Skor & 40 \\
\hline & Persentase & $53 \%$ \\
\hline & Kriteria & Valid \\
\hline
\end{tabular}

Tabel 5. Hasil Validasi Media terhadap LKPD Pengembangan

\begin{tabular}{|c|c|c|}
\hline No & Pernyataan & Skor \\
\hline 1. & LKPD sesuai tujuan pembelajaran & 2 \\
\hline 2. & $\begin{array}{l}\text { Bahan LKPD cukup untuk } \\
\text { mempelajari materi }\end{array}$ & 2 \\
\hline 3. & Materi LKPD tersusun sistematis & 3 \\
\hline 4. & $\begin{array}{l}\text { Bahasa sesuai dengan tingkat } \\
\text { perkembangan siswa }\end{array}$ & 3 \\
\hline 5. & $\begin{array}{l}\text { Jenis dan ukuran huruf dipilih } \\
\text { dengan tepat }\end{array}$ & 1 \\
\hline 6. & $\begin{array}{l}\text { Besar huruf dengan gambar } \\
\text { memiliki perbandingan yang } \\
\text { serasi }\end{array}$ & 2 \\
\hline 7. & $\begin{array}{l}\text { Susunan kalimat sederhana dan } \\
\text { mudah dipahami }\end{array}$ & 2 \\
\hline 8. & Struktur isi LKPD lengkap & 2 \\
\hline & Format LKPD disajikan menarik & 3 \\
\hline 10. & $\begin{array}{l}\text { Gambar tepat menyampaikan } \\
\text { pesan/isi secara efektif }\end{array}$ & 3 \\
\hline 11. & $\begin{array}{l}\text { Kombinasi sesuai antara gambar, } \\
\text { warna dan tulisan }\end{array}$ & 3 \\
\hline & Jumlah Skor & 40 \\
\hline & Persentase & $91 \%$ \\
\hline & Kriteria & $\begin{array}{l}\text { Sangat } \\
\text { Valid }\end{array}$ \\
\hline
\end{tabular}

Penilaian kepraktisan terhadap LKPD berbasis materi prasyarat terstruktur diperoleh dari persentase jawaban peserta didik dan guru melalui angket yang diberikan pada tiga tahap uji coba (Tabel $6)$.

Tabel 6. Rata-rata Persentase Skor Respon Peserta Didik pada Tahap-tahap Uji Coba

\begin{tabular}{|c|c|c|}
\hline $\begin{array}{c}\text { Tahap Uji } \\
\text { Coba }\end{array}$ & $\begin{array}{c}\text { Rata-rata } \\
\text { Persentase } \\
\text { Skor } \\
\end{array}$ & Kriteria \\
\hline $\begin{array}{l}\text { Uji Coba } \\
\text { Kelompok } \\
\text { Kecil }\end{array}$ & $99 \%$ & $\begin{array}{l}\text { Sangat } \\
\text { praktis }\end{array}$ \\
\hline $\begin{array}{l}\text { Uji Coba } \\
\text { Kelompok } \\
\text { Besar }\end{array}$ & $98 \%$ & $\begin{array}{l}\text { Sangat } \\
\text { praktis }\end{array}$ \\
\hline $\begin{array}{l}\text { Uji Coba } \\
\text { Kelompok } \\
\text { Sebenarnya }\end{array}$ & $99,5 \%$ & $\begin{array}{l}\text { Sangat } \\
\text { praktis }\end{array}$ \\
\hline $\begin{array}{l}\text { Skor Respon } \\
\text { Guru }\end{array}$ & $100 \%$ & $\begin{array}{l}\text { Sangat } \\
\text { praktis }\end{array}$ \\
\hline $\begin{array}{l}\text { Rata-rata } \\
\text { Persentase }\end{array}$ & $99 \%$ & $\begin{array}{l}\text { Sangat } \\
\text { praktis }\end{array}$ \\
\hline
\end{tabular}


Hasil belajar menggunakan produk LKPD yang dikembangkan diperoleh hasil sebanyak $76 \%$ peserta didik telah mencapai ketuntasan dengan KKM 68, dengan kriteria efektif. Efektif yang dimaksud adalah penggunaan LKPD berdampak positif terhadap pencapaian hasil belajar. Sesuai dengan teori tuntas, keberhasilan kelas dapat dilihat jika minimal $75 \%$ dari jumlah peserta didik mampu mencapai KKM (Djamarah \& Zain, 2010).

Penyebab kesulitan belajar, selain kurangnya pengetahuan prasyarat yang dimiliki peserta didik adalah pendekatan pembelajaran yang tidak tepat yang cenderung berpusat pada guru (Marniah, 2006). Keterbatasan buku sebagai sumber belajar di MTsN 6 Batanghari menjadi salah satu penyebab guru yang cenderung untuk menerapkan pembelajaran langsung.

Pemanfaatan LKPD dalam pembelajaran memberikan pengalaman belajar yang bermakna kepada peserta didik melalui kegiatan untuk membangun pengetahuannya sendiri. Penggunaan LKPD juga dapat menumbuhkan keaktifan belajar, sehingga peserta didik tidak hanya mendengarkan uraian guru. Meskipun demikian, dalam proses pembelajaran guru tetap berperan dalam memberikan bimbingan kepada peserta didik. Informasi yang terdapat pada LKPD yang diterapkan dalam situasi dan kondisi yang sama, mungkinkan tercipatanya keseragaman pengamatan dan persepsi peserta didik. Pemanfaatan LKPD dapat meningkatkan minat dan perhatian peserta didik sehingga mereka bisa lebih fokus dalam belajar sehingga memungkinkan penguasaan tujuan belajar lebih baik. Sebagaimana disampaikan Dwi dkk., (2012) bahwa pembelajaran dengan LKPD mampu meningkatkan aktivitas peserta didik, praktis digunakan, serta efektif dalam memperbaiki hasil belajar peserta didik.

\section{KESIMPULAN}

Berdasarkan rata-rata persentase skor yang diperoleh dari validator materi dan validator media, yakni $72 \%$ dapat dinyatakan bahwa LKPD matematika berbasis materi prasyarat terstruktur termasuk dalam kategori valid. LKPD tersebut dinilai sangat praktis digunakan dalam pembelajaran. Hal ini dapat dilihat dari rata-rata persentase respon peserta didik dari ketiga tahap uji coba serta respon guru yang mencapai 99\%. LKPD matematika berbasis materi prasyarat terstruktur dinilai efektif digunakan dalam pembelajaran yang ditunjukkan dari hasil belajar rata-rata peserta didik sebesar $76 \%$, dan telah mampu mencapai KKM.

\section{DAFTAR PUSTAKA}

Djamarah, S. B., \& Zain, A. (2010). Strategi Belajar Mengajar. Jakarta: PT Rineka Cipta.

Dwi, W., Dafik, D., \& Susanto, S. (2012). Pengembangan Perangkat Pembelajaran Matematika Berbasis Karakter Pada Pembelajaran Quantum Pokok Bahasan Persamaan Garis Lurus SMP kelas VIII. Kadikma, 3(3).

Hidayanto, T. (2013). Pengembangan Bahan Ajar Berbasis Realistic Mathematic Education Untuk Membangun Kemampuan Komunikasi Matematis Siswa SMP Kelas VIII pada Materi Fungsi. SKRIPSI Jurusan MatematikaFakultas MIPA UM.

Hidayat, S. (2013). Pembelajaran Matematika Dengan Model Advance Organizer Berbasis Materi Prasyarat Terstruktur Untuk Meningkatkan Pemahaman Konsep Dan Penalaran Matematis Siswa. Universitas Pendidikan Indonesia. 
Hidayati, F. (2010). Kajian Kesulitan Belajar Siswa Kelas VII SMP Negeri 16 Yogyakarta dalam Mempelajari Aljabar. Skripsi. Fakultas Matematika Dan Ilmu Pengetahuan Alam UNY: Yogyakarta (Tidak Dipublikasikan).

Mahdi, H. L. (2012). Penerapan Pemberian Materi Prasyarat dalam Pembelajaran Matematika di MAN 2 Model Banjarmasin.

Maisura, M. (2014). Remedial Teaching Matematika didasarkan pada Diagnosa Kesulitan Siswa Kelas II Madrasah Tsanawiyah. Jurnal Didaktik Matematika, 1(1).

Marniah. (2006). Meminimalkan Kesulitan Belajar Materi Persamaan Garis Lurus pada Siswa Kelas VIII-E SMP Negeri 4 Sidoarjo dengan Pendekatan Konstruktivis Penelitian Kelas. Universitas Malang.

Rohmad, A., Suhandini, P., \& Sriyanto, S. (2012). Pengembangan Lembar Kerja Siswa (LKS) Berbasis Eksplorasi, Elaborasi, dan Konfirmasi (EEK) Serta Kebencanaan Sebagai Bahan Ajar Mata Pelajaran Geografi SMA/MA di Kabupaten Rembang. Edu Geography, 1(2).

Sumiati, \& Asra, M.. (2009). Metode Pembelajaran. Bandung: Wacana Prima.

Suningsih, A., Kusmayadi, T. A., \& Riyadi, R. (2014). Eksperimentasi Model Pembelajaran Kooperatif Tipe TTW dan TPS pada Persamaan Garis Lurus Ditinjau dari Karakteristik Cara Berpikir Siswa SMP Negeri SeKabupaten Pringsewu. Jurnal Pembelajaran Matematika, 2(4).
Susanto, A. (2013). Teori Belajar dan Pembelajaran di Sekolah Dasar. Jakarta: Kencana prenada media group.

Tanjungsari, R. D., \& Soedjoko, E. (2012). Diagnosis Kesulitan Belajar Matematika SMP Pada Materi Persamaan Garis Lurus. Unnes Journal of Mathematics Education, 1(1).

Wulandari, R., \& Sunardi, S. (2014). Pengembangan Perangkat Pembelajaran Berbasis Pembelajaran Matematika Realistik Pokok Bahasan Kubus dan Balok. Pancaran Pendidikan, 3(1), 131-140. 